\title{
REALOKASI KEBIJAKAN FISKAL: IMPLIKASI PENINGKATAN HUMAN CAPITAL DAN PEMBANGUNAN INFRASTRUKTUR TERHADAP PERTUMBUHAN EKONOMI DAN KESEJAHTERAAN MASYARAKAT
}

\section{Reallocation Fiskal Policy: Implications For Enhancing Human Capital And Infrastructure Development On Economic Growth And Welfare Society}

\author{
Hayat Abdullah \\ Fakultas Ilmu Administrasi Universitas Islam Malang, \\ Jl. MT. Haryono 193 Malang, 65144, Telp. (0341) 565802 \\ Email: hayat.150318@gmail.com \\ Dikirim: 15 Maret 2014; direvisi: 25 Maret 2014; disetujui: 12 Mei 2014
}

\begin{abstract}
Abstrak
Pertumbuhan ekonomi bangsa terus mengalami berbagai perkembangan. Berbagai tantangan masih terus dihadapi ekonomi bangsa. Pada Asean Free Trade Area (AFTA) 2015 segera tiba, tantangan itu justru datang dari berbagai faktor, baik faktor internal (dalam negeri) maupun eksternal (luar negeri). Restrukturisasi sebagai bahan evaluasi dan pembangunan terhadap berbagai infrastruktur dan sarana prasarana perekonomian. Penetapan alokasi terhadap APBN maupun APBD menjadi kunci penting dalam pertumbuhan ekonomi bangsa. Problem utamanya adalah adanya korelasi yang tidak seimbang dalam pengelolaan fiskal. Begitu juga, pengeluaran dan pemasukan tidak berbanding lurus dengan pertumbuhan ekonomi dan kesejahteraan masyarakat. Tujuan dari penelitian ini adalah (1) untuk mendeskripsikan dan menganalisis implementasi realokasi fiskal sebagai preferensi bagi pemerintah dalam melakukan reformulasi kebijakan dan realokasi fiskal untuk pembangunan ekonomi yang berkelanjutan; (2) untuk mengetahui dan menganalisis pengaruh peningkatan human capital terhadap pertumbuhan ekonomi; dan (3) mendeskripsikan dan menganalisis hubungan pembangunan infrastruktur dengan pertumbuhan ekonomi terhadap kesejahteraan masyarakat. Oleh karena itu, untuk meningkatkan kesejahteraan masyarakat dibutuhkan sebah sinergi yang komprehensif antara human capital dan pembangunan infrastruktur yang memadai, tentunya hal ini harus didukung oleh adanya sebuah restrukturisasi fiskal dalam pengambilan kebijakan serta realokasi yang substantif dan akomodatif. Sehingga pada penerapan AFTA 2015, Indonesia siap menjadi trend setting di dalam peningkatan pertumbuhan ekonomi, kesejahteraan masyarakat, peningkatan sumber daya manusia dan pembangunan yang integratif.

Kata kunci: restrukturisasi dan realokasi fiskal, human capital, infrastruktur, pertumbuhan ekonomi, kesejahteraan masyarakat
\end{abstract}

\begin{abstract}
The growth of the nation's economy continues to experience a variety of developments. Various economic challenges still facing the nation. At the Asean Free Trade Area (AFTA) in 2015 soon arrives, the challenge is coming from a variety of factors, both internal factors (domestic) and external (foreign). Restructuring as the evaluation and development of various infrastructure and economic infrastructure. Determination of the state budget and the budget allocation to be of key importance in the economic growth of the nation. The main problem is that correlation is not balanced in fiskal management. Likewise, expenses and income is not directly proportional to the economic growth and social welfare. The purpose of this study was (1) to describe and analyze the implementation of fiskal reallocation as a preference for the government in the way of reformulating policy and fiskal reallocation for sustainable economic development; (2) to determine and analyze the effect of an increase in human capital to economic growth; and (3) describe and analyze the relationship between infrastructure development and economic growth of the welfare of society. Therefore, to improve the welfare of the people of obstruction takes a comprehensive synergy between human capital and the development of adequate infrastructure, of course, this must be supported by the existence of a fiskal restructuring and reallocation policy making substantive and accommodating. So that the implementation of AFTA in 2015, Indonesia is ready to be a trend setting in the economic growth, community welfare, human resource development and integrative development.

Keywords: restructuring and reallocation of fiskal, human capital, infrastructure, economic growth, community welfare
\end{abstract}

\section{PENDAHULUAN}

Ekonomi merupakan hal terpenting dalam pembangunan bangsa. Peran ekonomi sebagai jantung dalam pemerintahan yang mengatur segala hal berkaitan dengan kebijakan negara. Negara yang mempunyai tingkat ekonomi yang baik, mempunyai dampak positif terhadap kualitas dan kebutuhan 
Tabel 1. Proyeksi Pertumbuhan Ekonomi Global 2013 dan 2014

\begin{tabular}{lcccc}
\hline \multirow{2}{*}{ Wilayan/Negara } & \multirow{2}{*}{2011} & \multirow{2}{*}{2012} & \multicolumn{2}{c}{ Proyeksi } \\
\cline { 5 - 5 } & 3.9 & 3.2 & 2013 & 2014 \\
\hline Dunia & 1.7 & 1.5 & 1.2 & 3.6 \\
Negara-negara maju & 1.8 & 2.8 & 1.6 & 2.0 \\
Amerika Serikat & 1.5 & -0.6 & -0.4 & 1.0 \\
Zona Euro & -0.6 & 2.0 & 2.0 & 1.2 \\
Jepang & 9.3 & 7.7 & 7.6 & 7.3 \\
China & 6.2 & 4.9 & 4.5 & 5.1 \\
Negara-negara berkembang & 6.5 & 6.2 & 5.3 & 5.5 \\
Indonesia & &
\end{tabular}

Sumber: IMF World Economic Outlook October 2013, dalam http://www.portalreksadana.com/node/633 diakses tanggal 13 September 2014.

masyarakatnya, serta kesejahteraan bagi seluruh warganya. Pendidikan yang berkualitas, kesehatan yang baik yang memberikan pelayanan bagi kebutuhan masyarakat, ketersediaan kebutuhan di dalam negeri menjadi indicator utama dalam pencapaian ekonomi yang baik.

IMF (International Monetary Fund) pada tahun 2013 mencatat pertumbuhan ekonomi global mencapai 2,9\% sedangkan proyeksi pada tahun 2014 adalah 3,6\%. Namun secara umum, proyeksi global adalah 2,5\% selama paruh pertama 2013. Sementara itu, negara-negara berkembang termasuk Indonesia mengalami perlambatan, sekalipun dalam perkembangannya masih memberikan kontribusi yang lebih besar.

Perkembangan ekonomi Indonesia sudah mengalami berbagai kendala dan tantangan. Sejak 1997, krisis moneter yang melanda, dampak negative secara langsung dirasakan oleh masyarakat, sehingga kebutuhan di dalam negeri tidak mencukupi dan harus tergantung kepada negara lain di dalam melakukan penyediaan kebutuhan masyarakat. Begitu juga tingginya harga pangan di dalam negeri membuat resah dan panic bagi hampir seluruh masyrakat, pemangku kebijaknpun berusaha semaksimal mungkin untuk mengembalikan perekonomian dengan berbagai kebijakan dan implementasi yang dilakukan.

Namun seiring dengan berjalannya waktu, perbaikan sedikit demi sedikit terus dilakukan, berbagai kebijakan fiskal diaktualisasikan dengan orientasi kepada kepentingan publik dan kesejahteraan masyarakat, pelembagaan keuangan terus melakukan reformasi untuk menata ulang atau merekonstruksi aspek sumber daya manusia dan sumber daya infrastrukturnya, begitu juga dengan peran ekonomi masyarakat terus digeliatkan sebagai partisipasi peningkatan ekonomi Indonesia menuju negara mandiri dan berdaulat, ekonomi keberlanjutan terus digalakkan dengan reformulasi kebijakan di bidang keuangan negara dan perimbangan fiskal antara pemerintah pusat dan daerah sebagai penguatan terhadap ekonomi kerakyatan. Semua itu tentu mempunyai tujuan yang sama, yaitu untuk meningkatkan taraf hidup masyarakat yang lebih baik dan meningkatkan kesejahteraan masyarakat dalam menghadapi ekonomi global. Hal ini sebagai sarana untuk menjawab pertanyaan tentang bagaimana implementasi realokasi fiskal dalam pembangunan ekonomi? apakah human capital mempunyai pengaruh terhadap pertumbuhan ekonomi? dan apakah pembangunan infrastruktur dan pertumbuhan ekonomi dapat meningkatkan kesejahteraan masyarakat?

Penelitian yang dilakukan oleh Marno Kastowo (2011), mengenai peran modal manusia bagi pertumbuhan ekonomi dari tahun 1970-2008, bahwa modal manusia dengan usia harapan hidup, pendidikan dasar, dan produktivitas tenaga kerja terbukti memiliki pengaruh positif terhadap signifikansi pada pertumbuhan ekonomi. Upaya dalam melakukan peningkatan terhadap modal manusia melalui pendidikan, kesehatan dan produktivitas kerja perlu dilakukan secara konsisten untuk meningkatkan pertumbuhan ekonomi yang berkelanjutan.

Hasil penelitian Hadi Sasana (2009) menunjukkan bahwa pertumbuhan ekonomi mempunyai pengaruh terhadap tenaga kerja yang terserap, sehingga dapat berpengaruh terhadap kemiskinan. Disamping itu, pertumbuhan ekonomi mempunyai implikasi bagi kesejahteraan masyarakat yang ditopang oleh terserapnya tenaga kerja dalam perbaikan ekonomi dan meningkatkan penerimaan pemerintah. Sehingga pengurangan terhadap kemiskinan mempunyai peran penting dalam meningkatkan kesejahteraan masyarkat.

Sementara itu, Achmadi Sjafii (2009), dalam penelitian tentang pengaruh investasi fiskal dan investasi pembangunan manusia terhadap pertumbuhan ekonomi Jawa Timur 1990-2004, dengan menggunakan multiple linear regression menunjukkan bahwa investasi pembangunan fisik dan pembangunan modal manusia mempunyai pengaruh yang signifikan terhadap pertumbuhan ekonomi Jawa Timur. Investasi swasta dalam bidang pembangunan, pertumbuhan tenaga kerja, pembangunan manusia melalui kebijakan pemerintah, mempunyai peranan dalam meningkatkan pertumbuhan ekonomi di Jawa Timur. Sedangkan pembangunan manusia dibidang 
pendidikan dan kesehatan sangat diperlukan untuk meningkatkan kualitas sumber daya manusia yang ditampakkan ke dalam Indeks Pembangunan Manusia (IPM). IPM mempunyai signifikansi dalam memacu pertumbuhan ekonomi local, sehingga indeks kemiskinan manusia dapat ditekan seminimal mungkin.

Almasdi Syahza (2005) dalam penelitian tentang dampak pembangunan perkebunan kelapa sawit terhadap multiplier effect ekonomi pedesaan di daerah riau mengungkapkan bahwa kegiatan perkebunan kelapa sawit di pedesaan menciptakan angka multiplier effect sebesar 2,48, terutama dalam lapangan pekerjaan dan peluang berusaha. Tingkat pertumbuhan kesejahteraan petani kelapa sawit di Riau meningkat pada tahun 1995 sebesar 0,49. Tahun 2003 indek pertumbuhan kesejahteraan meningkat menjadi 1,72. Sehingga pertumbuhan dan pembangunan kelapa sawit mempunyai dampak ekonomi dan kesejahteraan bagi masyarakat pedesaan secara signifikan.

Penelitian yang dilakukan oleh Priyo Hari Adi (2006) mengatakan bahwa, pertumbuhan ekonomi daerah mempunyai dampak yang siginifikan terhadap peningkatan PAD (Pendapatan Asli Daerah). Disamping itu, belanjan pembangunan memberikan dampak positif dan signifikan terhadap PAD maupun pertumbuhan ekonomi. Hasil penelitiannya yang dilakukan melalui pengembangan riset sebelumnya terkait dengan hubungan antara pertumbuhan ekonomi daerah, belanja pembangunan dan pendapatan asli daerah yang mengatakan bahwa pertumbuhan ekonomi memberikan dampak positif bagi peningkatan PAD.

Tahlim Sudaryanto dan I Wayan Rusastra (2006) mengungkapkan bahwa kemampuan sector pertanian dalam peningkatan produksi dan pengentasan kemiskinan sangat bergantung pada kemampuannya dalam mengatasi kendala pengembangan yang dihadapi, yaitu keterbatasan pengembangan lahan beririgasi, teknologi varietas unggul, dan penyediaan sistem insentif untuk mendorong peningkatan produksi dan pendapatan petani. Kebijakan dalam pengembangannya adalah meningkatkan investasi pemerintah dalam pembangunan infrastruktur utama (irigasi, penelitian dan penyuluhan), mendorong dan menfasilitasi keterlibatan swasta dalam pembangunan pertanian, meningkatkan insentif usaha tani (input, output dan pasar), dan memfasilitasi perkembangan agroindustry pada tenaga kerja pedesaan.

David Hariyanto dan Priyo Hari Adi (2007) dalam penelitian tentang hubungan antara dana alokasi umum, belanja modal, pendapatan asli daerah dan pendapatan per kapita menunjukkan bahwa dari hasil uji hipotesis menunjukkan dana alokasi umum sangat berpengaruh terhadap belanja modal. Belanja modal mempunyai impact signifikan dan negative terhadap pendapatan per kapita secara langsung, pun demikian, mempunyai dampak positif dalam hubungan yang tidak langsung, yaitu melalui PAD. Sementara PAD mempunyai pengaruh terhadap pendapatan per kapita, namun pertumbuhan yang terjadi masih kurang merata dan seimbang, sehingga masih terjadi ketimpangan ekonomi antar daerah. Sementara dana alokasi umum secara keseluruhan mempunyai dampak yang signifikan terhadap pendapatan asli daerah melalui belanja daerah secara tidak langsung.

Hermanto Siregar dan Dwi Wahyuniarti (2008) mengungkapkan bahwa dari hasil analisis yang dilakukan adalah bahwa pertumbuhan ekonomi mempunyai pengaruh terhadap penurunan angka kemiskinan, walaupun pengaruh itu tidak besar. Begitu juga dengan tingkat populasi mempunyai peran dalam peningkatan penduduk miskin, namun pengaruhnya relative kecil. Sehingga dibutuhkan sebuah terobosan dan kebijakan yang strategis dalam mengatasi kemiskinan dan meningkatkan kesejahteraan masyarakat, yaitu dengan melakukan laju inflasi dan populasi yang seimbang dan terkendali, industrialisasi pertanian atau pedesaan yang tepat dan akumulasi modal manusia yang relative cepat harus dipenuhi. Pertumbuhan ekonomi menjadi syarat keharusan (necessary condition) dan kecukupan (sufficient condition) dalam mengurangi kemiskinan dan meningkatkan kesejahteraan.

Abdul Wahab (2009) mengungkapkan bahwa investasi infrastruktur mempunyai pengaruh yang signifikan terhadap meningkatnya aksesibilitas dan mobilitas penduduk dalam pengembangan kawasan pertanian. Disamping itu, adanya infrastruktur yang baik dapat memberikan akses yang lebih besar dalam berinteraksi dengan wilayah lainnya, sehingga dapat memanfaatkan lahan yang kurang produktif dapat dijadikan sebagai potensi untuk menghasilkan komoditi yang lebih baik. Hal ini menunjukkan bahwa, peningkatan kualitas jalan lingkar kawasan barat Enrekang ternyata sangat berpengaruh terhadap peningkatan kuantitas dan kualitas produksi komoditi pertanian. Adanya kualitas infrastruktur yang baik, diharapkan dapat menarik investor dalam mengembangkan investasinya pada kawasan tersebut. Oleh karena itu, investasi infrastruktur yang berkualitas, akan dapat memberikan pengaruh yang baik terhadap tingkat kesejahteraan bagi masyarakat, hal ini terbukti adanya peningkatan terhadap penghasilan penduduk masyarakat barat Enrekang.

Penelitian Chandra Darma Permana dan Alla Asmara (2010) menunjukkan bahwa infrastruktur memiliki keterkaitan ke belakang yang lebih tinggi dari pada keterkaitan ke depannya. Artinya bahwa, infrastruktur mempunyai peran penting dalam meningkatkan output sector lain untuk digunakan sebagai input dibandingkan meningkatkan outputnya itu sendiri. Infrastruktur lebih mampu meningkatkan pertumbuhan sector hulu dari pada hilirnya. Dampak dari infrastruktur mempunyai signifikansi yang besar terhadap multiplier dalam bidang ekonomi. Pun demikian, pertumbuhan investasi pada sector lainnya juga berdampak secara total terhadap pengentasan 
kemiskinan dan memberikan pendapatan yang lebih baik serta penguatan terhadap kualitas modal manusia.

\section{METODE PENELITIAN}

Penelitian ini menggunakan metode kualitatif dengan menggunakan pendekatan deskriptif. Alasannya adalah, karena penelitian ini merupakan penelitian pustaka, tujuannya adalah untuk mempermudah peneliti dan menemukan temuan penelitian secara obyektif dan komprehensif. Penarikan sampel dalam penelitian ini dilakukan dengan menyampaikan realitas dengan fakta-fakta yang ada serta berbagai pendapat para ahli terkait dengan topic yang diangka, dalam bentuk cetak maupun online.

Teknik pengambilan data, dilakukan dengan studi literature atau kajian kepustakaan. Peneliti mengkaji sampel data dan informasi yang pendapat ahli dari berbagai media online maupun cetak, buku, jurnal ilmiah, maupun tulisan-tulisan lainnya. Tahap analisis data menggunakan analisis deskriptif korelatif, yaitu mendeskripsikan dan mengintegrasikan berbagai data dan informasi yang dihubungkan dengan temuan atau hasil penelitian sebagai prinsip korelasi dan integrasi. Sehingga tujuan dari penelitian ini dapat tercapai secara komprehensif dan akumulatif.

\section{HASIL DAN PEMBAHASAN}

\section{Implementasi Realokasi Fiskal dalam Pembangunan Ekonomi}

Pelaksanaan kebijakan fiskal merupakan konstruktif yang terintegratif dalam pembangunan. Realokasi fiskal sebagai penentu dari tumbuh kembangnya perekonomian menjadi hal yang paling berpengaruh dalam berbagai program-program pemerintah dalam jangka tertentu. Fiskal mempunyai peran penting dalam dinamika dan konstelasi perekonomian bangsa. Keseimbangan dan keteraturan fiskal menjadi pemicu suksesi dari program kerja pemerintahan, terutama terkait dengan aspek yang krusial dalam kehidupan masyarakat. Dibutuhkan sebuah kebijakan yang strategis dalam menentukan realokasi fiskal untuk tujuan bagi kesejahteraan masyarakat dan meningkatkan pertumbuhan ekonomi bangsa yang lebih baik.

Adam Smith dalam Ahmad Ma'ruf dan Latri Wihastuti (2008), mengatakan bahwa dalam mendukung pertumbuhan ekonomi, fungsi pemerintah adalah memelihara keamanan dalam negeri dan pertahana, menyelenggarakan peradilan, dan menyediakan barang-barang yang tidak disediakan oleh swasta. Fungsi-fungsi tersebut menjadi tanggung jawab pemerintah dalam pemenuhannya dalam rangka menjamin keamanan dan ketentraman bagi masyarakat, perlakuan secara bijaksana dan adil serta penyediaan terhadap infrastruktur dan pembangunan. Hal itu dilakukan oleh pemerintah melalui kebijakan fiskal, yaitu pengaturan terhadap pendapatan dan pengeluaran negara yang semata-mata untuk kesejahteraan masyarkaat.

Strategi dalam perumusan kebijakan fiskal diarahkan kepada pemberian ruang bagi ditempuhnya kebijakan stimulus fiskal secara terukur yang memberikan akselerasi terhadap pertumbuhan ekonomi dan perbaikan pemerataan hasil pembangunan secara nasional dengan tetap menjaga kesinambungan fiskal . Langkah-langkahnya, antara lain: (1) memberikan insentif fiskal untuk kegiatan ekonomi strategis; (2) mendorong pembangunan infrastruktur; (3) meningkatkan kinerja BUMN dalam mendukung pembangunan infrastruktur, pemberdayaan koperasi, usaha mikro, kecil, dan menengah, dan (4) memanfaatkan utang untuk belanja produkti. (Kemenkeu, 2014).

Kebijakan fiskal mempunyai fungsi utama, yaitu fungsi alokasi, distribusi, dan stabilisasi. Fungsi alokasi adalah melakukan komposisi terhadap penyediaan barang serta proses penyeberan barang tersebut sesuai dengan kebutuhan dan alokasinya. Sementara untuk fungsi distribusi adalah menjamin terpenuhinya kebutuhan masyarakat terhadap kebutuhannya, dan menjamin distribusi pendapatan secara baik, adil dan merata. Pendistribusian harus menjamin terpenuhinya seluruh kebutuhan dan terhadap seluruh masyarakat, oleh masyarakat, dari masyarakat dan untu masyarakat. Sedangkan funsi stabilisasi adalah instrument untuk mempertahankan kesempatan kerja yang tinggi, stabilitasi yang normal, pertumbuhan yang tepat dengan aspek perhitungan terhadap dampak yang dapat ditimbulkannya. (Ahmad Ma'ruf dan Latri Wihastuti, 2008).

Kebijakan atas realokasi fiskal penting untuk dilakukan. Hal itu dilalui oleh refomasi ekonomi di berbagai bidang dan sector. Reformasi ekonomi sebagai langkah strategis dalam pengelolaan kebijakan fiskal . Sebagai langkah awal dalam pengembangan kebijakan fiskal, reformasi ekonomi harus diarahkan ke dalam tatanan dan sasaran yang tepat, baik dan berkualitas. Krisis moneter telah dilalui melalui berbagai rintangan dan tantangan ekonomi Indonesia. Pembangunan dan pemantapan ekonomi bangsa terus digerakkan ke dalam arah yang lebih baik. Perkembangan ekonomi nasional sudah cukup baik ketimbang negara-negara asia yang terkena dampak krisis moneter.

Boediono (2009), memberikan gambaran tentang langkah selanjutnya dalam mengelola kebijakan fiskal yaitu adanya reformasi fiskal yang lebih mengakar; reformasi perpajakan; reformasi kepabean; reformasi anggaran dan reorganisasi Departemen keuangan.

Reformasi fiskal yang lebih mengakar sebagai tujuan dari adanya proses konsolidasi yang berlajut dengan melembagakan unsur-unsru utama dalam mengelola keuangan negara. Sebagai sasaran utama dalam pengakaran terhadap reformasi fiskal adalah perpajakan, kepabean, dan anggaran. Reformasi fiskal yang melembaga dapat menjadikan penguat bagi 
Tabel 2. Pendapatan Negara, 2013-2014* (triliun rupiah)

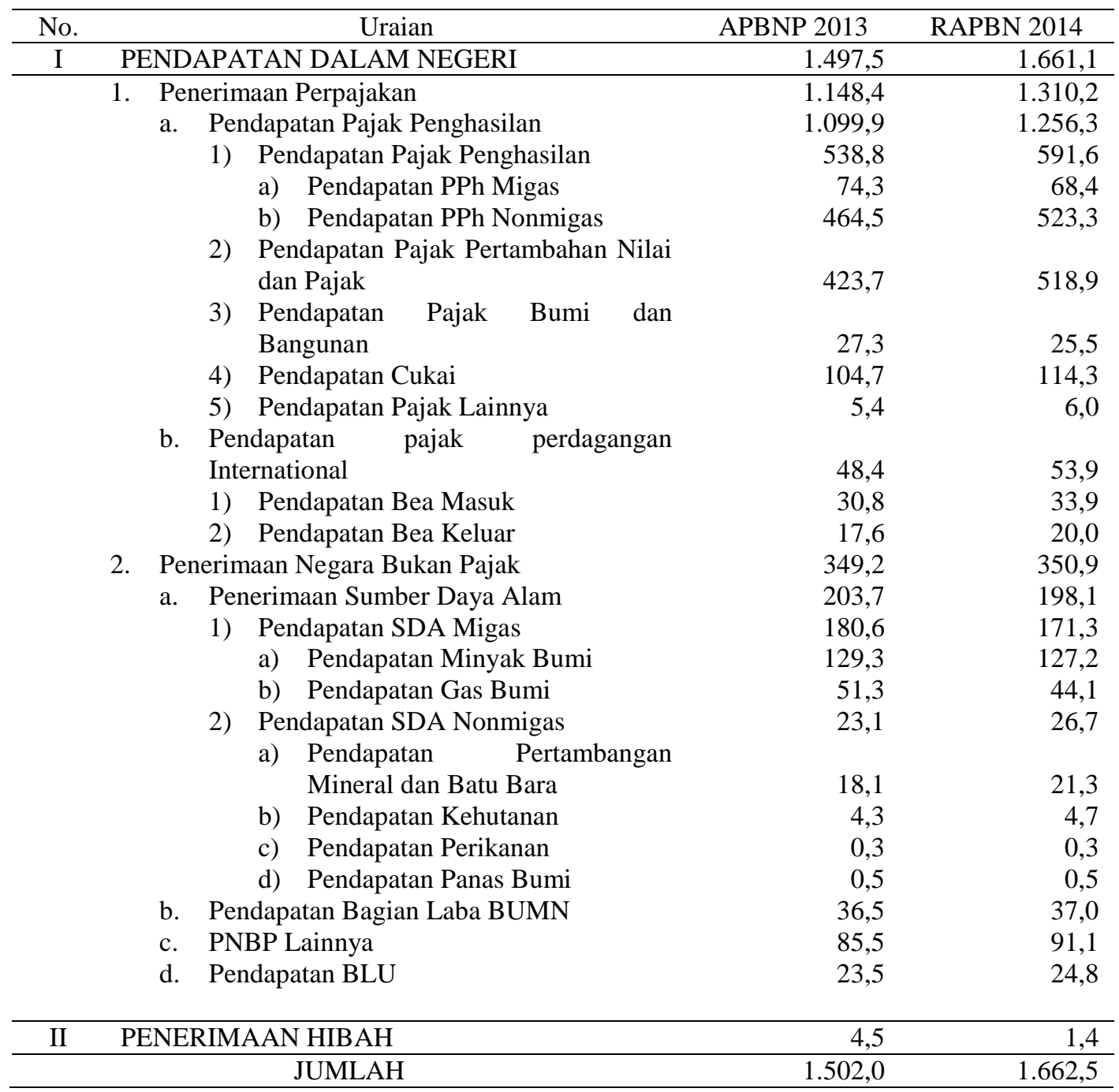

*perbedaan angka di belakang koma karena pembulatan

Sumber: Kementerian Keuangan, dalam Nota Keuangan dan Rancangan Anggaran Pendapatan dan Belanja Negara Tahun Anggaran 2014.

stakholders di dalamnya, sehingga proses transformasinya akan berjalan secara seimbang sesuai dengan ketentuan, kebutuhan dan kemanfaatannya.

Kementerian Keuangan mencatat dalam Nota Keuangan dan Rancangan Anggaran Pendapatan dan Belanja Negara Tahun Anggaran 2014. Pendapatan negara dalam tahun 2014, menurut data Kementerian Keuangan ditargetkan Rp. 1.662,5 triliun yang terdiri dari pendapatan dalam negeri Rp. 1.661,1 triliun, ditambah penerimaan hibah Rp. 1,4 triliun. Hal ini, menunjukan peningkatan dari APBN tahun 2013 yaitu Rp. 160,3 triliun (10,7\%).

Sementara itu, tindak lanjut kedua adalah reformasi perpajakan. Pendekatan yang dilakukan dalam reformasi dan modernisasi administrasi perpajakan menurut Boediono (2009) adalah dengan membentuk kantor percontohan dengan tata kerja baru yang didukung oleh sisitem teknologi informasi baru, otomatisasi administrasi, personalia yang diseleksi secara khusus dan professional, sistem sanksi dan insentif baru, serta sistem pengawasan secara otomatis.

Reformasi perpajakan merupakan langkah sistematik untuk memberikan pelayanan kepada wajib pajak dalam mentaati dan melakukan proses administrasi secara maksimal. Adanya reformasi administrasi dan mmodernisasi proses perpajakan, berimplikasi terhadap pendapatan asli daerah dari sector pajak, baik pajak perseorangan, fisik maupun kelompok usaha. Sistem yang dibangun secara elektronik memberikan kemudahan dan kebaikan bagi masyarakat sebagai pengguna layanan.

Reformasi perpajakan sudah dilakukan sejak tahun 1980an. Menurut Marzuki Usaman (2009), menyatakan bahwa pada awal masa orde baru pemerintah menargetkan fiskal yang mencakup diversifikasi penerimaan pemerintah dan ketergantungan atas pajak perdagangan international. 
Pada tahun 1970an, terpasung oleh boom minyak yang membantu meningkatkan anggaran pembangunan. Oleh karena itu, pajak dalam negeri menjadi terabaikan. Pada tahun 1980 pendapatan pajak non migas kurang dari 30 persen dari seluruh penerimaan pajak, dan mengakibatkan posisi fiskal menjadi tidak sustainable. Sehingga dilakukan reformasi pajak, tujuannya adalah: (1) untuk meningkatkan rasio penerimaan pajak nonmigas terhadap PDB (Produk Domestik Bruto); (2) untuk simflikasi hokum-hukum pajak dan perbaikan terhadap sisitem perpajakan; (3) untuk mengurangi distorsi ekonomi dalam pengalokasian sumber-sumber yang langka; dan (4) untuk memberikan keadilan bagi para wajib pajak.

Sementara itu, bergulirnya reformasi kebijakan fiskal sebagai langkah menciptakan kondusifitas perekonomian agar berjalan sesuai dengan arah tujuan bangsa. Reformasi kebijakan fiskal merupakan pengaturan terhadap output dan input keuangan negara untuk menstabilkan ekonomi bangsa. Namun, kebijakan ekonomi tidak menjamin sebuah kesejahteraan bagi masyarakat, karena pengaruh terhadap kebijakan non-ekonomi juga mempunyai implikasi terhadap ekonomi bangsa, misalnya konflik sosial, kesehatan, dan seringnya terjadi bencana alam. Sehingga aspek non-ekonomi berpengaruh terhadap kebijakan ekonomi yang sudah terbangun (Hendrin $\mathrm{H}$. Sawitri, 2006).

Reformasi kebijakan fiskal harus mengacu kepada reformasi makroekonomi. Artinya bahwa, kebijakan fiskal harus melakukan reformulasi secara berkala dengan berdasarkan asas kejujuran, keadilan, kebaikan, kebutuhan, dan berorientasi kepada peningkatan kesejahteraan rakyat. Realokasi fiskal sebagai langkah kebijakn fiskal tentunya harus melihat aspek kebijakan non-ekonomi, karena secara substansi, reformasi ekonomi harus diikuti oleh reformasi hokum, politik, sosial lingkungan.

Hendrin H. Sawitri (2006) mengungkapkan, ada beberapa alternative untuk mencapai kondusifitas fiskal bagi pemerintah, yaitu mengupayakan dalam meningkatkan penerimaan ekonomi di dalam negeri, meminimalisir ketergantungan terhadap utang luar negeri, dan menekan pengeluaran negara dengan melihat aspek prioritas serta melakukan pemberantasan terhadap korupsi secara massif dan komprehensif.

\section{Implikasi Peningkatan Human Capital terhadap Pertumbuhan Ekonomi}

Menurut Hastarini Dwi Atmanti (2005), mengungkapkan bahwa teori human capital adalah seseorang dapat meningkatkan penghasilannya melalui peningkatan pendidikan. Peningkatan pendidikan sebagai modal manusia dalam meningkatkan produktifitas kerja, dari pendidikan dasar hingga pendidikan tertinggi mempunyai pengaruh terhadap aspek produktifitas yang berpengaruh terhadap penghasilan dan pendapatan per kapita.
Sejalan dengan pendapat Atmanti, bahwa model akumulasi modal manusia atau human capital yang diformulasikan oleh Lucas (1988), yang mengatakan bahwa perekonomian terdiri dari agenagen yang berusaha memaksimalkan utilitas seumur hidup. Sementara itu, dalam penelitian Barro (1992), mengatakan bahwa modal manusia atau human capital yang diproyeksi rata-rata umur di atas 25 tahun mempunyai pengaruh terhadap pertumbuhan pendapatan per kapita secara riil.

Begitu juga dengan penelitian yang dilakukan oleh Baldaci, dkk. (2004) mengungkapkan bahwa modal pendidikan yang diproksi dari tingkat pendidikan dasar dan menengah serta modal kesehatan mempunyai pengaruh yang signifikan terhadap pertumbuhan ekonomi. Sementara itu, Hauoas dan Yagoubi (2005) dalam penelitiannya menemukan bahwa pertumbuhan ekonomi di 16 (enam belas) negara timur tengah dan afrika utara periode 1965-2000 menunjukkan bahwa modal manusia mempunyai pengaruh signifikan terhadap pertumbuhan ekonomi yang merupakan wujud dari pengembangan teknologi dalam meningkatkan produktifitasnya. Sedangkan penelitian yang dilakukan oleh Dewina dan Yamauci (2010) menunjukkan bahwa modal manusia yang diproksi dengan lama pendidikan tertinggi pada keluarga dikurangi dengan lama pendidikan kepala keluarga mempunyai pengaruh positif terhadap pendapatan per kapita keluarga (Marno Kastowo, 2011)

Representasi dari berbagai penelitian di atas, bahwa peran dan pengaruh modal manusia atau human capital mempunyai pengaruh yang signifikan dan positif terhadap pertumbuhan ekonomi. Dombusch et. al., (2004) dalam Hermanto Siregar dan Dwi Wahyuniarti (2008), menjelaskan bahwa model pertumbuhan ekonomi Solow yaitu berangkat dari fungsi produksi agregat seperti dalam rumus $\mathrm{Y}=$ A.F(K,L). Y sebagai output nasional atau pertumbuhan ekonomi, K merupakan capital (modal fisik), L adalah tenaga kerja atau sumber daya manusia (human capital), dan A. adalah teknologi. Pertumbuhan ekonomi (Y) akan meningkat ketika human capital atau tenaga kerja sebagai sumber daya manusia (K atau $\mathrm{L}$ ) atau keduanya meningkat. Faktor yang paling mempengaruhi dari $\mathrm{K}$ adalah investasi. Bagitu juga output nasional akan meningkat jika terjadi peningkatan terhadap teknologi yang diikuti oleh peningkatan sumber daya manusia yang kompeten. Sehingga dapat ditarik benang merahnya, bahwa pertumbuhan ekonomi yang menjadi salah satu aktornya adalah human capital.

Human capital sebagai kunci utama dalam pembangunan ekonomi bangsa. Pendidikan dan pelatihan serta berbagai aspek pengembangan sumber daya manusia sebagai human capital mempunyai peran sentral dalam meningkatkan pertumbuhan ekonomi. Pendidikan yang dilakukan sejak dini mempunyai pengaruh signifikan terhadap output nasional sebagai latar belakang dari peningkatan 
kualitas sumber daya itu sendiri. Semakin tingginya peran teknologi sebagai instrument dalam produksi, tidak lepas dari peran human capital sebagai pengelola, pelaksana, dan produksi dalam pertumbuhan ekonomi.

Oleh karena itu, peran human capital harus mengikuti perkembangan teknologi sebagai korelasi yang seimbang dalam produksi. Sehingga keduanya dapat berjalan seimbang, human capital sebagai pengendali dari aplikasi teknologi secara professional dan berkualitas. Tentunya tidak mudah untuk mendapatkan sumber daya manusia yang kompeten, membutuhkan sebuah regresi linier antara pendidikan, keterampilan, dan kecerdasan. Sehingga korelasi input sebagai human capital dan proses yang membentuk teknologi merupakan sebuah alat dalam produksi dapat berpengaruh secara signifikan terhadap output secara maksimal. Konsepsi utamanya adalah berada pada peran human capital yang terus mengalami dinamisasi pertumbuhan dan perkembangan sesuai dengan kebutuhan produksinya.

Namun, hasil penelitian yang dilakukan oleh Desi Dwi Bastias (2010) menunjukkan bahwa, variable perbaikan dan peningkatan pendidikan tidak mempunyai pengaruh yang significant terhadap pertumbuhan ekonomi indonesia. Begitu juga dengan jangka panjangnya, pendidikan tidak mempunyai implikasi yang signifikan terhadap pertumbuhan ekonomi. Hal ini terjadi menurut Ari Widodo (2010) dalam Desi Dwi Bastias (2010), menunjukkan di dalam penelitiannya yang menghasilkan sebuah kesimpulan bahwa pendidikan yang dikeluarkan oleh pemerintah tidak dapat berdiri sendiri sebagai variable independen. Pengeluaran pemerintah terhadap perbaikan pendidikan tidak serta merta secara langsung mengubah dan meningkatkan kualitas tenaga kerja, yang kemudian meningkatkan produktifitas kerja, produktifitas kerja mengarah kepada meningkatnya pertumbuhan ekonomi Indonesia.

Sedangkan teori human capital berpendapat bahwa, pendidikan dapat meningkatkan kualitas penduduk yang selanjutnya meningkatkan pertumbuhan ekonomi. Hal itu sejalan dengan penelitian yang dilakukan oleh Hadi Sasana (2009), mengungkapkan bahwa, untuk meningkatkan pertumbuhan ekonomi dapat dilakukan berbagai cara, yaitu revitalisasi pertanian dari hulu ke hilir, membantu pemasaran produk unggulan UMKM, memberikan bantuan modal, dan memfasilitasi program linkage kemitraan dengan win-win solution. Bagitu juga dengan adanya desentralisasi fiskal diharapkan pemerintah daerah tidak hanya mengejar pertumbuhan ekonomi yang tinggi, tetapi diharapkan dapat meningkatkan pembangunan yang berbasis manusia (human development) sebagai syarat meningkatkan kesejahteraan masyarakat yaitu melalui peningkatan kualitas pendidikan, kesehatan, dan pemenuhan kebutuhan primer bagi masyarakat.

Begitu juga dengan perhatian Schumpeterian dalam Meire (2004) dan Kuncoro (2010), yang menyatakan bahwa inovasi sangat relevan dengan pembangunan yang membedakan antara invention (penemuan), ide dan konsep, dan innovation (inovasi). Dikatakan bahwa ide harus menciptakan alat produksi baru yang ditimbulkan oleh inovasi, sehingga pembangunan dapat terjadi. Tipe inovasi ini menitikberatkan pada kinerja wirausaha. Wirausaha merupakan bentuk dari modal manusia (human capital) yang mengimplementasikan ide-ide melalui ilmu pengetahuan. Oleh karena itu, untuk meningkatkan pembangunan, maka secara otomatis harus meningkatkan sumber-sumber kewirausahaan sebagai modal pertumbuhan ekonomi.

Oleh karena itu, reformulasi kebijakan fiskal dapat diarahkan kepada jalur ekonomi kerakyatan yang berorientasi terhadap kesejahteraan rakyat. Begitu juga dengan kebijakan fiskal yang berimbang antara pemerintah pusat dan daerah dalam melakukan realokasi harus sesuai dengan prinsip dasar change and balance dalam pelaksanaannya. Aspek human capital menjadi prioritas pemerintah pusat dan daerah dalam melakukan pembangunan melalui pendidikan yang berkualitas.

Menurut Siregar (2006), dalam Hermanto Siregar dan Dwi Wahyuniarti (2008), menyatakan bahwa pertumbuhan ekonomi merupakan suatu keharusan untuk mengurangi kemiskinan, sedangkan syarat kecukupan adalah pertumbuhan ekonomi yang efektif dalam meminimlisir kemiskinan. Artinya bahwa, pertumbuhan ekonomi merupakan kewajiban yang harus dipenuhi oleh pemerintah, terutama bagi pemerintah daearah dengan diberlakukannya desentralisasi fiskal . Pertumbuhan ekonomi merupakan kohesi yang terus ditingkatkan untuk meningkatkan kualitas ekonomi masyarakat sebagai representasi dari pengurangan terhadap kemiskinan. Pertumbuhan ekonomi juga tidak harus menfokuskan kepada pendapatan daerah, namun pembangunan infstruktur juga dapat digerakkan sebagai sistem yang terbangun dalam peningkatan ekonomi.

Pertumbuhan ekonomi yang dibangun atas dasar human capital, maka dapat berimplikasi terhadap kesejahteraan rakyat secara merata. Kesejahteraan tidak hanya berdasarkan kepada aspek peningkatan ekonomi masyarakat, akan tetapi penguatan terhadap kualitas sumber daya manusia, kualitas kesehatan, terkendalinya aspek sosial dan politik, serta keadilan berdasarkan hokum mempunyai signifikansi yang koheren dalam pertumbuhan ekonomi. Sehingga kesejahteraan dapat ditafsirkan keadalam tatanan masyarakta yang aman, adil, baik, dan berkualitas.

Bambang Saputra (2013), menyatakan bahwa tujuan akhir dari sebuah kebijakan ekonomi adalah untuk meningkatkan kesejahteraan rakyat. Satusatunya cara untuk meningkatkan penghasilan masyarakat dan membuka lapangan pekerjaan adalah dengan meningaktkan pertumbuhan ekonomi merupakan implementasi dari kebijakan dan perluasan kegiatan ekonomi. 
Sementara itu, Kuncoro (2004), mengungkapkan bahwa pertumbuhan ekonomi dan kesejahteraan masyarakat mempunyai hubungan yang sangat erat. Hipotesis yang dilakukan melalui trickle down effect (dampak merembes ke bawah) bahwa pertumbuhan ekonomi yang cepat akan menetes pada kesejahteraan masyarakat. Lebih lanjut Mankiw (2007) mengemukakan bahwa dalam jangka panjang, kapasitas negara untuk memproduksi barang dan jasa menentukan standar hidup penduduknya (Bambang Saputra, 2013)

Hubungan modal manusia sebagai subyek terhadap peningkatan pertumbuhan ekonomi didukung oleh produktifitas yang dilakukan sebagai effect dalam pendidikan, kesehatan dan lingkungan. Modal manusia yang baik dan berkualitas mempunyai signifikansi pengaruh yang sangat positif terhadap peningkatan produksi. Peningkatan produksi yang baik berpangaruh terhadap peningkatan ekonomi. Sehingga jelas, bahwa peningkatan ekonomi dapat dipengaruhi oleh faktor manusia sebagai produksi utama dalam pertumbuhan ekonomi dan meningkatkan penghasilan per kapita.

Dukungan sarana prasana dalam produksi juga ditentukan oleh kualitas dan modal manusia yang dibangun di dalamnya. Pertumbuhan dan perkembangan teknologi juga dibangun atas dasar kemampuan manusia untuk menghasilkan produktifitas yang lebih baik. Sehingga apa yang dikatakan oleh Mankiw bahwa kapasistas negara dalam meningkatkan pertumbuhan ekonominya tergantung dari kualitas dan profesionalitas modal manusianya (human capital). Human capital yang baik dan pertumbuhan ekonomi yang terus berkembang mempunyai implikasi secara sistematis terhadap kesejahteraan bagi masyarakat, sebagai sebuah cita-cita bangsa yang agung demi terciptanya masyarakat yang adil dan sejahtera.

Rasidin K. Sitepu (2010), memperkuat pentingnya investasi sumber daya manusia sebagau human capital terhadap peningkatan pertumbuhan ekonomi. Peningkatan human capital dalam produktivitas tenaga kerja mempunyai implikasi yang baik terhadap deficit anggaran pemerintah. Hal itu dibuktikan oleh menurunnya deficit anggaran pemerintah sebesar 10.74 triliun. Human capital dapat pula meningkatkan pertumbuhan manusia secara mandiri dan meminimalisir terjadinya pembiasaan masyarakat terhadap menggantungkan kehidupannya kepada pemerintah.

\section{Korelasi Pembangunan Infrastruktur dengan Pertumbuhan Ekonomi}

Menurut penelitian yang dilakukan World Bank (2004) bahwa rendahnya investasi dapat disebabkan oleh rendahnya ketersediaan infrastruktur dan sarana dan prasarana publik, sehingga integrasi ekonomi tidak dapat berjalan dengan baik dan terwujud, hal itu berdampak secara positif terhadap pertumbuhan ekonomi. Sementara itu, menurut P. Eko Prasojo
(2009) dalam Tommy Prio Haryanto (2013), menyatakan bahwa pertumbuhan ekonomi dapat diartikan sebagai pertmbahan output atau pendapatan nasional agregat dalam kurun waktu tertentu. Sementara menurut Todaro (2006) definisi pertumbuhan ekonomi adalah proses peningkatan ekonomi melalui proses kapasistas produksi meningkat dalam menghasilkan pendapatan (Tommy Prio Haryanto, 2013).

Teori pertumbuhan ekonomi melalui evolusi ekonomi mengemukakan berbagai pendapat tentang makroekonomi. Lynn (2002) mengungkapkan bahwa kemakmuran hanya mengakumulasikan emas dan perak, sementara negara hanya mempunyai peran mendapatkan sebanyak-banyaknya. Sementara Smith mengemukakan bahwa kemakmuran negara di dapatkan dari kemampuannya dalam mengaktualisasikan sumber daya alam dan sumber daya manusia untuk menghasilkan produksi yang lebih baik, dengan menekankan pada kompetensi yang dimiliki masing-masing individu (Kuncoro, 2010).

Pertumbuhan ekonomi menurut penulis adalah adanya peningkatan terhadap PDB nasional yang diikuti oleh peningkatan terhadap modal manusia sebagai subyek produksi untuk menghasilkan output yang lebih baik dan berkualitas. Peningkatan modal manusia, tentunya diikuti oleh pembangunan infrastruktur yang lebih baik dan perbaikan terahadap sarana prasarana publik sebagai aksesibilitas, penunjang pergerakan ekonomi, dan penopang ekonomi kerakyatan dengan pengelolaan dan pengembangan ekonomi local sebagai unggulan usaha serta peningkatan penghasilan per kapita keluarga.

Sedangkan pertumbuhan ekonomi harus didukung oleh peningkatan pembangunan modal manusia dan peningkatan infrastruktur publik. Sehingga pendapatan keuangan negara dapat berjalan secara berimbang dengan pengeluaran sebagai modal dari peningkatan dan pertumbuhan ekonominya. Tingginya pengembangan modal manusia sebagai subyek dalam meningkatkan kualitas infrastruktur dan sebagai pengembang di dalam perwatan terhadap saran dan prasaran publik, mempunyai implikasi yang sangat positif didalam meningkatkan pertumbuhan ekonomi.

Menurut Engla Desnim Silvia, Yuniat Wardi, dan Hasdi Aimon (2013), mengatakan bahwa penyediaan dan perbaikan terhadap infrastruktur mampu meningkatkan pertumbuhan ekonomi yang mengarah kepada kesejahteraan masyaarakat. Penyediaan dan perbaikan terhadap infrastruktur dapat memperlancar proses produksi barang dan jasa. Hal ini dapat meningkatkan pertumbuhan ekonomi. Sealnjutnya, dalam kesimpulannya, dikatakan bahwa, secara parsial pengeluaran pemerintah baik rutin dan pembangunan mempunyai pengaruh positif terhadap pertumbuhan ekonomi Indonesia.

Pembahasan di atas jelas bahwa pertumbuhan ekonomi dipengaruhi oleh kualitas infrastruktur yang dibangun sesuai dengan kebutuhan dan kelayakan. 
Infrastruktur sebagai jembatan utama dalam peningkatan perekonomian, baik secara local maupun nasiona. Hal ini sejalan dengan hasil penelitian yang dilakukan oleh Youdhi Permadi Ma'ruf dan Jeluddin Daud (2013) menunjukkan scatter plot antara PDRB (Produk Domestik Regional Bruto) dan total panjang jalan dan jembatan dengan pola penyebaran data menggambarkan trend pertumbuhan positif setiap tahuannya, yaitu dari tahun 2006 sampai dengan tahun 2010. Hal ini menunjukkan dengan adanya pertambahan panjang jalan dan jembatan dapat berimplikasi terhadap peningkatan PDRB kabupaten pesisir Selatan.

PDRB yang baik dengan pertumbuhan ekonomi yang signifikan mempunyai pengaruh terhadap kesejahteraan rakyat. Pertumbuhan ekonomi dapat dikembangkan ke dalam program-program kerakyatan yang mendukung pola dan modal manusia yang berkualitas. Sehingga perputaran ekonomi, tidak hanya berjalan pada tataran jangka pendek, tetapi jangk panjang dengan meningkatkan infrastruktur untuk kesejahteraan masyarakat lebih penting.

Sejalan dengan itu, seperti penelitian yang dilakukan oleh Abdul Wahab (2009) tentang dampak peningkatan kualitas jalan lingkar barat Enrekang terhadap pengembangan kawasan pertania, menunjukkan bahwa adanya perbaikan terhadap jalan lingkar jalan kawasan pertanian dapat meningkatkan aksesibilitas masyarakat dalam pengembangan pertanian. Sehingga infrastruktur yang baik mendapatkan akses yang cukup, akses yang cukup dapat berpengaruh terhadap nilai pertumbuhan yang dibangun atas dasar peningkatan perekonomian pertanian dan peningkatan nilai-nilai ekonomi pertanian yang dapat diaktualisasikan ke dalam bentuk kesejahteraan rakyat.

Peningkatan infrastruktur pertanian dapat juga dapat meningkatkan nilai tanah pada daerah pertanian, meningkatkan perekonomian masyarakat melalui penghidupan kembali tanah daerah, yang semula merupakan tanah mati, dengan adanya kualitas jalan dapat dialiri oleh air, sehingga dapat menghidupkan kembali tanah untuk pertanian. Pertanian dalam jalan lingkar dengan dilengkapi oleh saluran dan irigasi air, dapat mengembangkan pertanian kawasan lingkar jalan. Sehingga masyarakat dapat mengembangkan ekonomi pertanian yang ada dengan aksesibilitas untuk meningkatkan kesejahteraan rakyat.

Namun, berbanding terbalik penelitian yang dilakukan oleh Desi Dwi Bastias (2010), terkait dengan singkronisasi infrastruktru dengan pertumbuhan ekonomi. Dikatakan bahwa pembangunan sector infrastruktur dalam hal ini adalah perumahan dan jalan. variable infrastruktur perumahan dalam penelitian ini tidak mempunyai pengaruh yang signifikan terhadap pertumbuhan ekonomi Indonesia. Pembangunan perumahan dilihat dari probabilitasnya t-statistk yang lebih besar dari alpha 5 persen. Sementara pada infrastruktur transportasi atau jalan, variable ini mempunyai pengaruh yang signifikan terhadap pertumbuhan ekonomi Indonesia, baik dalam jangka pendek maupun jangka panjang.

Artinya, bahwa infrastruktur jalan atau transportasi mempunyai pengaruh dan dampak yang nyata terahdap pertumbuhan ekonomi Indonesia. Infrastruktur jalan yang baik, menciptakan aksesibilitas bagi masyarakat dalam menggerakkan perekonomian. Aksesibilitas sebagai proses percepatan terhadap ekonomi, baik dalam skala local mauplun nasional. Aksesibilitas sebagai proses peningkatan terhadap ekonomi Indonesia mempunyai pengaruh yang positif terhadap pertumbuhan ekonomi. Ekonomi yang semakin baik dengan pertumbuhan melalui infrastruktur membeikan dampak terhadap kesejahteraan rakyat.

Pertumbuhan ekonomi melalui peningkatan infrastruktur mempnyai pengaruh secara langsung dalam ekonomi masyarakat. Infrastruktur denga penguatan terhadap aksesibilitas dapat mengembangkan perekonomian masyarakat. Perekonomian masyarakat yang berjalan dengan baik dapat meningkatkan taraf hidup dan penghasilan per kapita. Pengaruh aksesibilitas dan pertumbuhan ekonomi masyarakat yang dapat meningkatkan pertumbuhan ekonomi Indonesia. Peningkatan ekonomi masyarakat dalam penelitian ini dapat diaktualisasikan kedalam kesejahteraan masyarakat. Masyarakat yang mempunyai penghasilan ekonomi yang baik, dapat memjamin kehidupan masyarakat yang berkualitas.

\section{SIMPULAN}

Berdasarkan hasil penelitian dan pembahasan di atas, dapat disimpulkan bahwa dibutuhkan restrukturisasi dalam pengalokasian fiskal . Alokasi fiskal yang ada saat ini masih jauh dari harapan pertumbuhan ekonomi. Problematika muncul di dalam perkembangan alokasi fiskal yang kurang merata antara suatu daerah dengan daerah lainnya. Sasaran alokasi fiskal juga masih belum tepat dalam tataran negara berkembang, serta struktur kelembagaan keuangan negara membutuhkan restruktursi sebagai preferensi dan pengkondisian serta pendistribusian sumber daya manusia, sumber daya alam (struktur) dan sumber daya ekonomi. Alokasi fiskal mempunyai pengaruh yang signifikan terhadap pertumbuhan ekonomi.

Sementara itu, pertumbuhan ekonomi dipengaruhi oleh keberadaan human capital. Peningkatan human capital yang diaplikasikan melalui pendidikan, perilaku, dan sikap sebagai modal manusia dapat berdampak dan berimplikasi terhadap pertumbuhan ekonomi. Sehingga alur kesinambungan antara ketiganya (alokasi fiskal , pertumbuhan ekonomi, dan human capital) tidak dapat dipisahkan dalam integrasi sasaran dan tujuan pemerintahan, yaitu kesejahteraan bagi seluruh rakyat Indonesia. 
Ekonomi masyarakat yang kuat, mempunyai pengaruh terhadap ekonomi Indonesia, dengan penguatan terhadap aksesibilitas infrastruktur dan peningkatan sumber daya manusia sebagi modal manusia dalam pembanguan ekonomi indoensia. Peningakatan ekonomi ditentukan oleh sarana dan prasarana yang dibangun, termasuk infrastruktur yang ada di dalamnya. Infrastruktur yang berkualitas dapat meningkatkan pertumbuhan ekonomi.

Berdasarkan simpulan di atas, maka dapat dikemukakan bebarapa rekomendasi antara lain: Pertama, dibutuhkan reformulasi kebijakan publik yang mencakup seluruh komponen stakeholder, yaitu public (pemerintah), private (swasta), dan community (masyarakat). Sehingga dapat dirumuskan kembali arah kebijakan fiskal dengan orientasi yang berdasarkan pada keadilan dan kesejahteraan bagi seluruh rakyat Indonesia. Baik perencanaan dan implementasi kebijakan melalui alokasi fiskal yang tepat sasaran dan sesuai dengan kebutuhan serta evaluasi kebijakan yang menjadikan rekomendasi dalam memperbaiki dan melakukan tinjauan yang berfokus pada peningkatan ekonomi dan kesejahteraan rakyat. Pun demikian, tentunya harus dibangun dengan asas aksesibility, transparency, dan akuntability. Sehingga adanya restrukturisasi dan realokasi fiskal berdampak terhadap peningkatan human capital dan pembangunan infrastruktur.

Kedua, perlu diadakan percepatan terahadap restrukturisasi dan realokasi fiskal yang tepat dan strategis secara nasional dan lokal. Restrukturisasi terhadap pelembagaan ekonomi Indonesia dengan pelbagai perbaiakn terhadap sumber daya manusia, sarana dan prasarana, serta peningkatan partisipasi melalui kerjasama public, private, dan community sebagai kekuatan ekonomi Indonesia. Diperlukan kebijakan dalam meningkatkan modal manusia melalui peningkatan kualitas pendidikan, kesehatan, dan pelatihan terhadap pengelolaan ekonomi loka sebagai ekonomi unggulan dalam kehidupan masyarakat. Kebijakan kemudahan modal juga dapat membantu human capital dalam mengaplikasikan modal manusianya ke dalam peningkatan produksi sebagai reproduksi pertumbuhan ekonomi yang lebih baik.

Ketiga, diperlukan kebijakan terhadap pembangunan infrastruktur secara merata dan setara pada setiap pemerintahan daerah. Dibutuhkan sebuah kebijakan yang konkrit dalam pembangunan infrastruktur untuk menunjang ekonomi pemerintah daerah melalui kebijakan perimbangan fiskal antara pusat dan daerah. Pembangunan yang merata pada setiap daerah akan berdampak terhadap ekonomi masyarakat dalam memperoleh akses ekonomi, pergerakan ekonomi yang cepat berkembang, dan akses transportasi yang meningkat seiring dengan infrastruktur yang baik. Sehingga ekonomi masyarakat dapat terbangun secara sinergi antara pembangunan infrastruktur dan pertumbuhan ekonomi masyarakat yang berkelanjutan sebagai penguatan terhadap kesejahteraan rakyat.

\section{DAFTAR PUSTAKA}

Adi, Priyo Hari. 2006. Hubungan Antara Pertumbuhan Ekonomi Daerah, Belanja Pembangunan dan Pendapatan Asli Daerah. Simposium Nasional Akuntansi IX di Padang, tanggal 23-26 Agustus 2006.

http://digilib.mercubuana.ac.id/manager/file_artikel _abstrak/Isi_Artikel_862943946606.pdf. Diakses tanggal 12 Juli 2014.

Atmanti, Hastarini Dwi. 2005. Investasi Sumber Daya Manusia Melalui Pendidikan. Jurnal Dinamika Pembangunan. 2 (1). Juli: 30-39.

Bastias, Desi Dwi. 2010. Analisis Pengaruh Pengeluaran Pemerintah Atas Pendidikan, Kesehatan dan Infrastruktur Terhadap Pertumbuhan Ekonomi Indonesia Periode 1969-2009. Skripsi. Semarang: Fakultas Ekonomi Universitas Diponegoro.

Boediono. 2009. Kebijakan Fiskal: Sekarang dan Selanjutnya. Era Baru Kebijakan Fiskal: Pemikiran, Konsep dan Implementasi. Anggito Abimayu dan Andi Megantara (Ed). Jakarta: PT. Kompas Media Nusantara, hal. 109-122.

Harianto, David dan Adi, Priyo Hari. 2007. Hubungan Antara Dana Alokasi Umum, Belanja Modal, Pendapatan Asli Daerah dan Pendapatan Per Kapita. Simposium Nasional Akuntansi X yang diselenggarakan oleh Universitas Hasanuddin Makasar, tanggal 26-28 Juli 2007. http://digilib.mercubuana.ac.id/manager/file_artikel _abstrak/Isi_Artikel_162620147808.pdf. Diakses tanggal 12 Juli 2014.

Haryanto, Tommy Prio. 2013. Pengaruh Pengeluaran Pemerintah Terhadap Pertumbuhan Ekonomi Kabupaten/Kota Di Provinsi Jawa Tengah Tahun 2007-2011. Economic Development Analysis Journal, Volume 2, Nomor 3. (Online). http://journal.unnes.ac.id/sju/index.php/edaj. Diakses tanggal 15 Juli 2014.

Kastowo, Marno. 2011. Peran Modal Manusia Bagi Pertumbuhan Ekonomi: Studi Empirik Di Indonesia 1970-2008. http://pusdiklatwas.bpkp.go.id/artikel/namafile/91/ MODALMANUSIA.pdf. Diakses tanggal 15 Juli 2014.

Kuncoro, Mudrajad. 2010. Masalah, Kebijakan dan Politik Ekonomi Pembangunan. Jakarta: Erlangga.

Ma'ruf, Ahmad dan Wihastuti, Latri. 2008. Pertumbuhan Ekonomi Indonesia: Determinan dan Prospeknya. Jurnal Ekonomi dan Studi Pembangunan. 9 (1). April: 44-55.

Ma'ruf, Youdhi Permadi dan Daud, Jeluddin. 2013. Pengaruh Investasi Infrastruktur Jalan Terhadap Pertumbuhan Ekonomi Wilayah Di Kabupaten Pesisir Selatan Provinsi Sumatera Barat. Jurnal Tekni Sipil USU. 2 (3). (Online). http://jurnal.usu.ac.id/index.php/jts/article/view/568 0/2400. Diakses tanggal 17 Juli 2014. 
Wiria, Melinda. N. 2013. IMF World Economic Outlook October 2013, dalam http://www.portalreksadana. com/node/633 diakses tanggal 13 September 2014.

Permana, Chandra Darma dan Asmara, Alla. 2010. Analisis Peranan Dan Dampak Investasi Infrastruktur Terhadap Perekonomian Indonesia: Analisis Input-Output. Jurnal Management \& Agribisnis. 7 (1). Maret: 48-58.

Republik Indonesia. 2014. Nota Keuangan dan Rancangan Anggaran Pendapatan dan Belanja Negara Tahun Anggaran 2014. Jakarta: Kementerian Keuangan RI.

Saputra, Bambang. 2013. Pengaruh Desentralisasi Fiskal Terhadap Pertumbuhan Ekonomi dan Kesejahteraan Masyarakat. Jurnal Borneo Administrator. 9 (1): 96-111.

Sasana, Hadi. 2009. Peran Desentralisasi Fiskal Terhadap Kinerja Ekonomi Di Kabupaten/Kota Provinsi Jawa Tengah. Jurnal Ekonomi Pembangunan. 10 (1). Juni: 103-124.

Sawitri, Hendrin H. 2006. Dampak Defisit Anggaran Terhadap Pertumbuhan Ekonomi. Jurnal Organisasi dan Manajemen. 2 (1). Maret: 1-10.

Silvia, Engla Desnim dan Wardi, Yuniat dan Aimon, Hasdi. 2013. Analisis Pertumbuhan Ekonomi, Investasi, dan Inflasi Di Indoensia. Jurnal Kajian Ekonomi. 1 (2). Januari: 224-243.

Siregar, Hermanto dan Wahyuniarti, Dwi. 2008. Dampak Pertumbuhan Ekonomi Terhadap Penurunan Jumlah Penduduk Miskin. http://pse.litbang.deptan.go.id/ind/pdffiles/PROS_2 008_MAK3. Diakses tanggal 12 Juli 2014.

Sitepu, Rasidin K. 2010. Dampak Investasi Sumber Daya Manusia dan Bantuan Langsung Tunai Terhadap Distribusi Pendapatan Rumah Tangga di Indonesia. Jurnal Keuangan dan Moneter. 13 (2): 129-156.

Sjafii, Achmad. 2009. Pengaruh Investasi Fiskal dan Investasi Pembangunan Manusia Terhadap Pertumbuhan Ekonomi Jawa Timur 1990-2004. Journal of Indonesian Applied Economics. 3 (1). Mei: 59-76.

Sudaryanto, Tahlim dan Rusastra, I Wayan. 2006. Kebijakan Strategis Usaha Pertanian Dalam Rangka Peningkatan Produksi dan Pengentasan Kemiskinan. Jurnal Litbang Pertanian. 25 (4): 115-122.

Syahza, Almasdi. 2005. Dampak Pembangunan Perkebunan Kelapa Sawit Terhadap Multiplier Effect Ekonomi Pedesaan Di Daerah Riau. Jurnal Ekonomi. Th. X/03/Nopember: 1-12.

Usaman, Marzuki. 2009. Reformasi Sektor Fiskal dan Finansial Indonesia dalam Dekade 1970-an dan 1980-an. Era Baru Kebijakan Fiskal: Pemikiran, Konsep dan Implementasi. Anggito Abimayu dan Andi Megantara (Ed). Jakarta: PT. Kompas Media Nusantara, hal. 47-57.

Wahab, Abdul. 2009. Dampak Peningkatan Kualitas Jalan Lingkar Barat Enrekang Terhadap Pengembangan Kawasan Pertanian. Tesis. Semarang: Program Pascasarjana Magister Teknik Pembangunan Wilayah dan Kota Universitas Diponegoro. 
